\title{
Garcia Resigns as Arizona University VP
}

Dr. Joe G.N. "Skip" Garcia resigned his administrative duties as senior vice president for health sciences at the University of Arizona. Garcia said he would devote his full attention as a professor at the UA College of Medicine-Tucson according to the Arizona Republic (1). "After much thought and reflection, I have decided that the time is right for me to take a step back and focus on my continually growing research commitments," Garcia said. "Please know that this decision was an exceptionally difficult one and not reached lightly, and that I am humbled by all of your support during my time as senior vice president."

Garcia was hired in 2013 to oversee the university's medical schools in Phoenix and Tucson, as well as the schools of nursing, pharmacy and public health. Shortly after Garcia was hired, he reorganized UA health sciences, recruited a roster of academics and tightened oversight of the Phoenix medical school. However, after Dr. Stuart Flynn, the Phoenix medical school's longtime dean, and most of his leadership team resigned to join the staff of a newly created medical school in Fort Worth, Texas, Garcia faced increasing scrutiny and criticism. The departures prompted the Arizona Medical Association, a physicians' organization with 4,000 members, to ask the Arizona Board of Regents to interview the departed leaders as part of an investigation of the school's management.

In August, the regents' health affairs committee held public hearings in Tucson and Phoenix to gather input from medical-school stakeholders. The regents also hired an independent consultant to evaluate concerns about the two medical schools. The consultant delivered a report to the regents, who concluded in October following a closed-door meeting that no further action was needed. Even though the Board of Regents spent $\$ 179,653$ in public funds on the report, the regents have refused to provide a copy of the report to the public, citing attorneyclient privilege and work-product protections.

UA President Ann Weaver Hart who previously announced she would leave the president's post in 2018 praised Garcia's track record. "The work accomplished by Dr. Skip Garcia in just three short years as the senior vice president for health sciences has had a profound impact on the future of the College of MedicineTucson, the College of Medicine-Phoenix, and the Colleges of Pharmacy, Nursing and Public Health at the University of Arizona," Hart said in a statement released by the university.

Garcia is a pulmonary physician whose research focused on the genetic basis of lung disease and the prevention and treatment of inflammatory lung injury (2). He had previously served in academic positions at the University of Texas Health Center at Tyler, Indiana University School of Medicine, Johns Hopkins University School of Medicine, the University of Chicago, and the University of Illinois at Chicago before coming to Arizona. He has been continuously funded by the $\mathrm{NIH}$ since 1988 and has authored or co-authored more than 400 peer-reviewed 
publications and over 35 book chapters. In 2016, Dr. Garcia received the Trudeau Medal from the American Thoracic Society in recognition of his lifelong major contributions to the prevention, diagnosis and treatment of lung disease through leadership in research, education and clinical care.

Richard A. Robbins, MD

Editor, SWJPCC

\section{References}

1. Alltucker K. Joe 'Skip' Garcia, the embattled University of Arizona med-school chief, quits his VP post. Arizona Republic. December 8, 2016. Available at: http://www.azcentral.com/story/news/local/arizona/2016/12/08/embattled-uamed-school-chief-quits-vp-post-to-return-to-teaching-and-research/95156932/ (accessed 12/9/16).

2. The University of Arizona Health Sciences. Joe G. N. "Skip" Garcia, MD biography. Available at: http://uahs.arizona.edu/senior-vice-president-healthsciences/joe-garcia-bio (accessed 12/9/16). 